\title{
ROOT CONSTITUENTS OF LACTUCA SIBIRICA AND A COMPARISON OF METABOLITE PROFILES OF L. SIBIRICA AND L. TATARICA
}

\author{
KLAUdia MichaLSKA, WANDA KisIEL \\ Department of Phytochemistry, Institute of Pharmacology, \\ Polish Academy of Sciences \\ Smętna 12, 31-343 Kraków, Poland \\ e-mail: kisielw@if-pan.krakow.pl
}

(Received: June 5, 2008. Accepted: October 4, 2008)

\begin{abstract}
Nine known sesquiterpene lactones, including four lactucin-type guaianolides, four costuslactone-type guaianolides and one germacranolide, were isolated from roots of Lactuca sibirica (Asteraceae), six of which were glycoside derivatives. The chemosystematic significance of the compounds is discussed in the context of sesquiterpenoids present in roots of the closely related species Lactuca tatarica. A comparison of sesquiterpene lactone profiles indicate that the species can be differentiated on the basis of their germacranolide glycoside compositions.
\end{abstract}

KEY WORDS: Lactuca sibirica, L. tatarica, Asteraceae, sesquiterpene lactones, chemotaxonomy.

\section{INTRODUCTION}

The genus Lactuca (Asteraceae, tribe Lactuceae), comprising approximately 100 species, is divided into seven sections and two (African and North American) geographical groups. The section Mulgedium (Cass.) C.B. Clarke is represented mainly by Lactuca sibirica (L.) Benth. ex Maxim. and Lactuca tatarica (L.) C.A. Mey., occurring in continental Europe and Asia. Lactuca taraxacifolia Schum. et Thonn. is a newly described species from the mountains of central Asia. Members of this section are herbaceous perennials with blue, lilac, rarely white florets (Doležalová et al. 2002; Koopman et al. 1998; Lebeda et al. 2004).

Chemically, plants of the genus Lactuca can be characterized by the accumulation of sesquiterpene lactones, consisting mainly of guaianolides and germacranolides, and phenolic compounds, among others (Kim et al. 2007; Kisiel and Barszcz 1997; Kisiel and Michalska 2008; Terencio et al., 1991 and references cited herein). L. sibirica has received little attention, apart from the work done recently in our laboratory, on its aerial parts from which four lactucin-type guaianolides and three furofuran lignans, including two new acylated glycosides of $4 \alpha, 8 \alpha$-dihydroxypinoresinol, have been isolated (Kisiel and Michalska 2008). For L. tatarica, a previous chemical study has been carried out on the whole plant extract, resulting in the isolation of lactucin and its ester lactucopicrin (Akyev et al. 1990). Our investigation of the plant roots has led to the isolation of lactucin and its four derivatives, three costus lactone-type guaianolides and four germacranolides, accumulated mainly as glycosides (9 compounds) (Kisiel et al. 1997; Kisiel and Barszcz 1998). It should be pointed out that we could find no sesquiterpene lactones in the aerial part extract. From the extract the flavonoid aglycones apigenin and luteolin have been isolated, in addition to apigenin-7-O- $\beta$ -glucopyranoside, kaempferol- and quercetin-3-O- $\beta$-glucopyranosides (Kisiel 1998).

Phylogenetic relationships among Lactuca species inferred from ITS-1 DNA sequences and AFLP fingerprints were studied by Koopman et al. (1998 and 2001) and the close relationship between the section Mulgedium species, represented by $L$. sibirica and L. tatarica, was corroborated. Therefore, the purpose of the present study was to characterize the sesquiterpene lactone composition in roots of L. sibirica and to compare it with that found in L.tatarica. Below, we describe the isolation of compounds 1-9 (Fig. 1) from the hitherto not studied roots of L. sibirica.

\section{MATERIAL AND METHODS}

\section{Plant material}

Roots of L. sibirica were collected in August 2004 from plants growing in the Garden of Medicinal Plants, Institute of Pharmacology, Polish Academy of Sciences, Krakow, Poland, where a voucher specimen (04/133) was deposited. Seeds of wild origin collected in Finland (Aavaranta, $62^{\circ} 37^{\prime} \mathrm{N}, 29^{\circ} 42^{\prime} \mathrm{E}$ ) were obtained from the Botanical Garden in Joensuu.

\section{Extraction and isolation}

The dried and powdered plant material (29 g) was exhaustively extracted with $\mathrm{EtOH}$ at room temperature. After removing the solvent under reduced pressure, a resi- 
<smiles>[R20]CC1=CC(=O)C2=C(C)C[C@@H]([R2])[C@H]3C(=O)C(=O)O[C@H]3[C@]12[CH]</smiles>

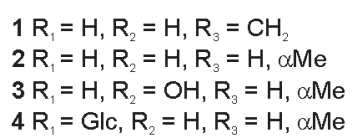

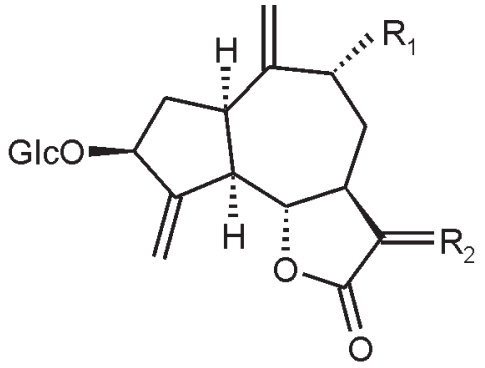

$5 \mathrm{R}_{1}=\mathrm{H}, \mathrm{R}_{2}=\mathrm{CH}_{2}$

$6 \mathrm{R}_{1}=\mathrm{H}_{1} \mathrm{R}_{2}=\mathrm{H}, \alpha M e$ $7 \mathrm{R}_{1}=\mathrm{OH}, \mathrm{R}_{2}=\mathrm{CH}_{2}$ $8 \mathrm{R}_{1}=\mathrm{OH}, \mathrm{R}_{2}=\mathrm{H}, \alpha \mathrm{Me}$

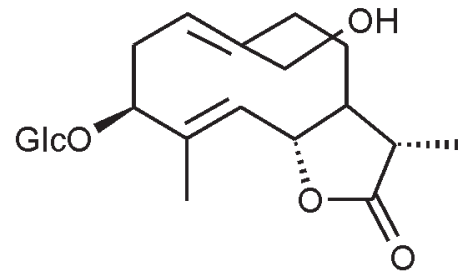

9
Fig. 1. Chemical structures of sesquiterpene lactones isolated from roots of Lactuca sibirica $($ Glc $=\beta$-glucopyranosyl $)$. due (4 g) was obtained, which was subjected to column chromatography on silica gel (Merck, Art. 7754), using hexane-EtOAc (up to $100 \%$ EtOAc), followed by EtOAc$\mathrm{MeOH}$ (up to $10 \% \mathrm{MeOH}$ ) gradient solvent systems. Fractions containing identical compounds were combined, after TLC analysis. The final step of purification was performed by preparative TLC (Merck, Art. 5553) and semipreparative HPLC on a Delta-Pak C-18 column (particle size $15 \mu \mathrm{m}$, $25 \times 100 \mathrm{~mm}$ ) coupled to a dual wavelength UV/Vis detector operating at 210 and $260 \mathrm{~nm}$, using a $\mathrm{H}_{2} \mathrm{O}-\mathrm{MeOH}(7: 3)$ mixture at a flow rate of $3.0 \mathrm{ml} \mathrm{min}-1$. Fractions eluted with hexane-EtOAc (1:1) gave a ca. 1:2 mixture of 1 and 2 (8.1 $\mathrm{mg})$ and $3(3.6 \mathrm{mg})$, after separation by preparative TLC $\left(\mathrm{CHCl}_{3}-\mathrm{MeOH}, 9: 1\right)$. Fractions from EtOAc elution contained sesquiterpene lactone glycosides. Initial fractions were separated by preparative TLC $\left(\mathrm{CHCl}_{3}-\mathrm{MeOH}, 9: 1\right)$ to give a ca. 3:0.5 mixture of 5 and $\mathbf{6}(24.4 \mathrm{mg})$. Further fractions were separated by preparative TLC $\left(\mathrm{CHCl}_{3}-\mathrm{MeOH}, 17: 3\right)$ and semipreparative HPLC to afford $4(18.8 \mathrm{mg}), 7$ (4.4 $\mathrm{mg}), \mathbf{8}(3.9 \mathrm{mg})$, and $\mathbf{9}(10.3 \mathrm{mg})$. The isolated compounds were identified as follows: 8-deoxylactucin (1), jacquinelin (2), 11ß, 13-dihydrolactucin (3), crepidiaside B (4), vernoflexuoside (glucozaluzanin C, 5), 11 $\beta$, 13-dihydroglucozaluzanin $\mathrm{C}(\mathbf{6})$, macrocliniside $\mathrm{A}(\mathbf{7})$, ixerin $\mathrm{F}(\mathbf{8})$, and $3 \beta$, 14-dihydroxy-11 $\beta$, 13-dihydrocostunolide-3-O- $\beta$-glucopyranoside (9) (Fig. 1). The compounds were readily characterized by direct comparison (HPLC, ${ }^{1} \mathrm{H}$ NMR, 300.18 $\mathrm{MHz}$ ) with reference compounds from our collection isolated from Lactuca species (Kisiel and Barszcz 1997; Stojakowska et al. 1994).

\section{RESULTS AND DISCUSSION}

Our chemical study of the roots of $L$. sibirica has led to the isolation of four lactucin-type guaianolides (1-4), four costus lactone-type guaianolides (5-8), and one germacranolide (9), known as constituents of some other Lactuca species, e.g. L. virosa (Kisiel and Barszcz 1997). Of these, the guaianolides $2, \mathbf{4 , 6 - 8}$ are common constituents of $L$. sibirica and $L$. tatarica. Both species can be differentiated based on their germacranolide glycoside compositions. The

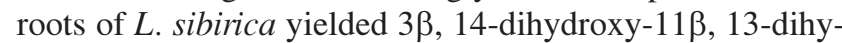
drocostunolide-3-O- $\beta$-glucopyranoside (9), while the roots of $L$. tatarica afforded four different costunolide derivatives, including 3 $\beta, 11 \beta$, 14-trihydroxy-11,13-dihydrocostunolide-3-O- $\beta$-glucopyranoside (tataroside) (Kisiel and Barszcz 1998). Costunolide derivatives hydroxylated at C3 and $\mathrm{C}-14$ or C-3, C-11 and C-14 are rare natural products. Compound $\mathbf{9}$ and its aglycone have been found in $L$. virosa (Kisiel and Barszcz 1997) and L. sativa (Mahmoud et al. 1986), respectively, while tataroside has not been reported from other plant sources. The compounds seem to be restricted to the genus Lactuca. Moreover, L. sibirica can be differentiated by the accumulation of acylated glycosides of furofuran lignans in its aerial parts (Kisiel and Michalska 2008). The flavonoids isolated from the aerial parts of L. tatarica (Kisiel 1998) are quite common constituents in Lactuca species (Hou et al. 2003; Kim et al. 2007; Kisiel and Zielińska 2000; Terencio et al. 1991).

Conclusively, these results indicate that germacranolides and lignans are reliable taxonomic markers within the section Mulgedium.

\section{LITERATURE CITED}

AKYEV B.A., OVEZDURDYEV A., SHAMYANOV I.D., MALIKOV V.M. 1990. Guaianolides of Lactuca tatarica. Khim. Prir. Soedin. 26: 265-267.

DOLEŽALOVÁ I., KŘíSTKOVÁ E., LEBEDA A., VINTER V. 2002. Description of morphological characters of wild Lactuca L. spp. genetic resources. Hort. Sci. (Prague) 29: 56-83.

HOU C.C., LIN S.J., CHENG J.T., HSU F.L. 2003. Antidiabetic dimeric guaianolides and a lignan glycoside from Lactuca indica. J. Nat. Prod. 66: 625-629. 
KIM K.H., KIM Y.H., LEE K.R. 2007. Isolation of quinic acid derivatives and flavonoids from the aerial parts of Lactuca indica L. and their hepatoprotective activity in vitro. Bioorg. Med. Chem. Lett. 17: 6739-6743.

KISIEL W. 1998. Flavonoids from Lactuca quercina and L. tatarica. Acta Soc. Bot. Pol. 67: 247-248.

KISIEL W., BARSZCZ B.1997. Minor sesquiterpene lactones from Lactuca virosa. Phytochemistry 46: 1241-1243.

KISIEL W., BARSZCZ B. 1998. A germacrolide glucoside from Lactuca tatarica. Phytochemistry 48: 205-206.

KISIEL W., BARSZCZ B., SZNELER E. 1997. Sesquiterpene lactones from Lactuca tatarica. Phytochemistry 45: 365-368.

KISIEL W., MICHALSKA K. 2008. Lignans and sesquiterpenoids from Lactuca sibirica. Fitoterapia 79: 241-244.

KISIEL W., ZIELIŃSKA K. 2000. Sesquiterpenoids and phenolics from Lactuca perennis. Fitoterapia 71: 86-87.

KOOPMAN W.J.M., ZEVENBERGEN M.J., van den BERG R.G. 2001. Species relationships in Lactuca s.l. (Lactuceae,
Asteraceae) inferred from AFLP fingerprints. Am. J. Bot. 88: 1881-1887.

KOOPMAN W.J.M., GUETTA E., van de WIEL C.C.M., VOSMAN B., van den BERG R.G. 1998. Phylogenetic relationships among Lactuca (Asteraceae) species and related genera based on ITS-1 DNA sequences. Am. J. Bot. 85: 1517-1530.

LEBEDA A., DOLEŽALOVÁ I., FERAKOVÁ V., ASTLEY D. 2004. Geographical distribution of wild Lactuca species (Asteraceae, Lactuceae). Bot. Rev. 70: 328-356.

MAHMOUD Z.F., KASSEM F.F., ABDEL-SALAM N.A., ZDERO C. 1986. Sesquiterpene lactones from Lactuca sativa. Phytochemistry 25: 747-748.

STOJAKOWSKA A., MALARZ J., KISIEL W. 1994. Sesquiterpene lactones in tissue culture of Lactuca virosa. Planta Med. 60: 93-94.

TERENCIO M.C., SANZ M.J., FONSECA M.L., MANEZ S., RIOS J.L. 1991. Phenolic compounds from Lactuca viminea L. Z. Naturforsch. 47c: 17-20. 